Acta Horticulturae et Regiotecturae 1

Nitra, Slovaca Universitas Agriculturae Nitriae, 2017, pp. 24-27

\title{
VALIDATION OF HYDRUS 1D MODEL IN SELECTED CATCHMENT OF SLOVAKIA
}

\author{
Andrej TÁRNÍK*, Dušan IGAZ \\ Slovak University of Agriculture in Nitra, Slovak Republic
}

\begin{abstract}
Soil water content is very important for agricultural practice. Direct measurements of the soil moisture are being replaced by mathematical simulations and models step by step. One of the most used models for the simulation of the soil moisture is HYDRUS 1D model. This paper deals with HYDRUS 1D validity check in the Nitra River Catchment. Three different localities in the Nitra River Catchment (Malanta, Kolíňany and Dolné Naštice) were chosen for model validity check. Both, measurements and modelling of soil moisture, were made for these localities in three years $(8 / 2011-8 / 2014)$. The evaluation of model validity was performed by calculation of the correlation coefficient and count of comparisons with variance of $15 \%$. The correlation coefficients of measured and simulated data were between 0.67 and 0.95 . Data comparisons with variance of $15 \%$ among measured and simulated data were between 79 to $100 \%$. Based on these results we can declare that HYDRUS 1D model is valid for the conditions of Slovak catchments.
\end{abstract}

Keywords: HYDRUS 1D, soil moisture, simulation, model validation

Global climate has changed dramatically in recent years. These changes influence every sphere of our lives, including agriculture. Difficulties with soil cultivation are caused by changes in average annual temperature and average annual rainfall. Soil water content and soil moisture are changing too. Soil water content in vadose zone is an important resource of water for plants. Water and solute movement in the unsaturated zone is an incredibly complex process due to the heterogeneous nature of soil and variable atmospheric boundary conditions at the soil surface over a short time period (Saifadeen and Gladnyeva, 2012). Knowing the amount and the dynamics of the soil water content, we may predict and react to the current climatic conditions of the environment in time (Jurík and Kaletová, 2014).

Realization of field soil moisture monitoring could be characterized as extremely time and money consuming (Kaletová et al., 2012; Šimůnek et al., 2012a). Because of this, we use mathematical models and simulations. The use of models and information systems is supported by increasing development of technologies (Leitmanová et al., 2014). Mathematical simulation is a modern tool for exact determination of desired parameters. Numerical models are increasingly used to predict or analyze the water flow and contaminant transport processes in the subsurface, including the vadose zone (Šimúnek, van Genuchten and Šejna, 2012b). Many of the authors used HYDRUS 1D model for the simulation of soil moisture (Burger and Látečka, 2005; Kaletová et al., 2012; Joris and Feyen, 2003; Šimůnek, et al., 2012c; Zeng, Su and Wan et al., 2009).

We need to do validity check of mathematical models due to their frequent use to obtain the soil moisture data. This paper is focused on the validity of outputs from the mathematical model HYDRUS 1D.

\section{Material and methods}

The HYDRUS 1D numerical model is widely used to simulate water flow and solute transport in variably saturated soils and groundwater. HYDRUS 1D software can be used to simulate such processes as precipitation, irrigation, infiltration, evaporation, transpiration, soil water storage, capillary rise, deep drainage and groundwater recharge (Šimůnek, van Genuchten and Šejna, 2012b).

Model validity check was performed by comparing measured data and HYDRUS 1D simulation outputs. Measured and simulated data from three different regions of the Nitra River Catchment (Malanta, Kolíňany and Dolné Naštice) in three different time periods (1. 8.-31. 10. 2011 for locality Malanta, 10. 6.-10. 8. 2014 for locality Kolíňany and 10. 1.-10. 2. 2014 for locality Dolné Naštice) were chosen for the comparison.

The Nitra River Catchment is the sub-catchment of the Váh River Catchment area. The Nitra River is located entirely in the Slovak Republic. Area of the Catchment is $5,080 \mathrm{~km}^{2}$. The Nitra River Catchment is mainly agricultural land ( $61 \%$ of the area) and forest land (30\% of the area). There are Rendzic Leptosols in the northern part and Chernozems, Mollic Fluvisols and Brown soils in the southern part of our Catchment (Landscape Atlas of the Slovak Republic, 2015; Jarabica et al., 2003; Šimanský, Tobiašová and Chlpík, 2008).

Soil moisture was measured in 20 and $40 \mathrm{~cm}$ depths of soil profile by the sensor 10HS (Decagon Devices). These sensors use frequency domain reflectometry (Decagon Devices, 2014). The evaluation of model validity was performed by calculation of the Pearson's correlation 
coefficient (1) and count of comparisons with variance of $15 \%$. Soil samples were taken from selected localities in the Catchment for determination of soil properties. Samples were analysed to obtain retention curves of soil. Data from the analysis were used as an input data of the HYDRUS 1D model.

$$
\rho_{X, Y}=\frac{\operatorname{cov}(X, Y)}{\sigma_{X} \sigma_{Y}}
$$

where:

cov - the covariance

$\sigma_{x} \quad$ - the standard deviation of $X$

$\sigma_{y} \quad$ - the standard deviation of $Y$

\section{Results and discussion}

Three localities with different climatic and soil conditions were chosen for validity check of HYDRUS 1D model. Both, measurements and modelling of soil moisture, were made for these localities. We chose different time periods (1. 8.-31. 10. 2011 for locality Malanta, 10. 6.-10. 8. 2014 for locality Kolínany and 10. 1.-10. 2. 2014 for locality Dolné Naštice) for this comparison.

The correlation coefficients of measured and simulated data were between 0.67 and 0.95 . Coefficient $r=0.60$ to 0.79 is considered as strong and $r=0.80$ to 1.0 as a very strong relationship (Clay, 2008). Count of comparisons with variance of $15 \%$ was a second parameter which was evaluated. Count of comparisons with variance of $15 \%$ between measured and simulated data was between 79 to $100 \%$.

Table 1 Correlation of measured and simulated data of soil moisture in locality of Malanta

\begin{tabular}{|l||c|c|c|c|c|c|c|}
\hline Time period & $\begin{array}{c}\text { Count of comparison } \\
\text { (each depth) }\end{array}$ & \multicolumn{2}{|c|}{$\begin{array}{c}\text { Count of comparisons with } \\
\text { variance of 15\% }\end{array}$} & $\begin{array}{c}\text { Count of comparisons with } \\
\text { variance of 15\%) }\end{array}$ & \multicolumn{2}{c|}{$\begin{array}{c}\text { Correlation } \\
\text { coefficient }\end{array}$} \\
\hline \hline \multirow{2}{*}{ 1.8.-31. 10.2011 } & \multirow{2}{*}{92} & $20 \mathrm{~cm}$ & $40 \mathrm{~cm}$ & $20 \mathrm{~cm}$ & $40 \mathrm{~cm}$ & $20 \mathrm{~cm}$ & $40 \mathrm{~cm}$ \\
\cline { 2 - 8 } & & 73 & 86 & 79.35 & 93.48 & 0.67 & 0.75 \\
\hline
\end{tabular}

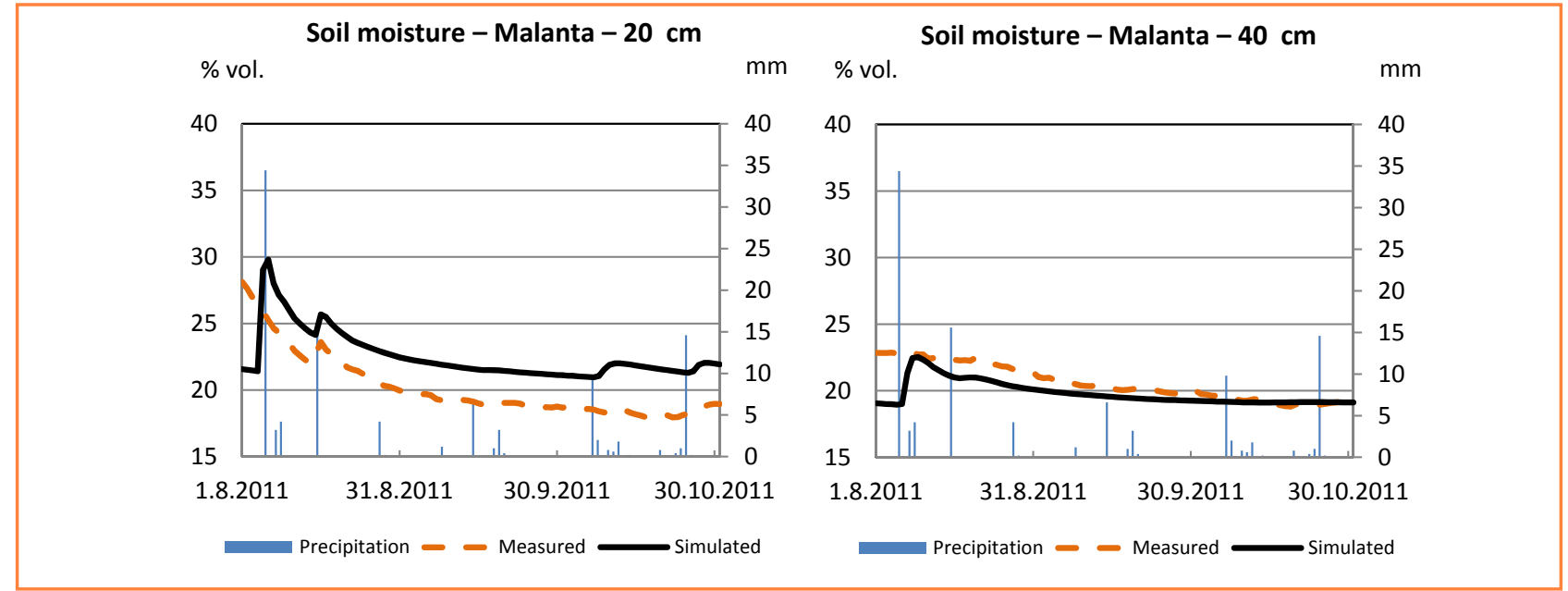

Figure 1 Measured and simulated data of soil moisture in the locality of Malanta

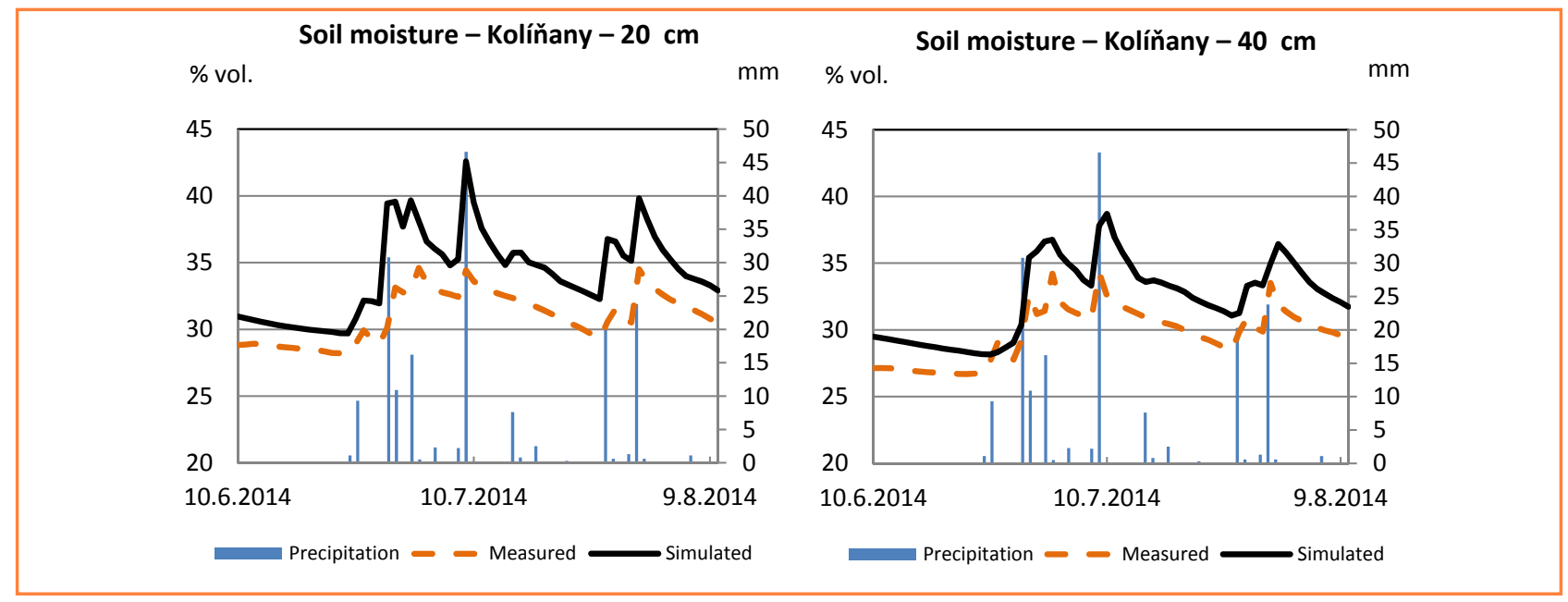

Figure 2 Measured and simulated data of soil moisture in the locality of Kolínany 
Table 2 Correlation of measured and simulated data of soil moisture in the locality of Kolíñany

\begin{tabular}{|l||c|c|c|c|c|c|c|}
\hline Time period & $\begin{array}{c}\text { Count of comparison } \\
\text { (each depth) }\end{array}$ & \multicolumn{2}{|c|}{$\begin{array}{c}\text { Count of comparisons with } \\
\text { variance of 15\% }\end{array}$} & \multicolumn{2}{c|}{$\begin{array}{c}\text { Count of comparisons } \\
\text { with variance of 15\%) }\end{array}$} & \multicolumn{2}{|c|}{$\begin{array}{c}\text { Correlation } \\
\text { coefficient }\end{array}$} \\
\hline \hline \multirow{2}{*}{ 10. 6.-10.8.2014 } & \multirow{2}{*}{62} & $20 \mathrm{~cm}$ & $40 \mathrm{~cm}$ & $20 \mathrm{~cm}$ & $40 \mathrm{~cm}$ & $20 \mathrm{~cm}$ & $40 \mathrm{~cm}$ \\
\cline { 3 - 8 } & & 51 & 58 & 82.26 & 93.55 & 0.90 & 0.95 \\
\hline
\end{tabular}

Table 3 Correlation of measured and simulated data of soil moisture in the locality of Dolné Naštice

\begin{tabular}{|l||c|c|c|c|c|c|c|}
\hline Time period & $\begin{array}{c}\text { Count of comparison } \\
\text { (each depth) }\end{array}$ & \multicolumn{2}{c|}{$\begin{array}{c}\text { Count of comparisons with } \\
\text { variance of 15\% }\end{array}$} & $\begin{array}{c}\text { Count of comparisons with } \\
\text { variance of 15\% (\%) }\end{array}$ & \multicolumn{2}{c|}{$\begin{array}{c}\text { Correlation } \\
\text { coefficient }\end{array}$} \\
\hline \hline \multirow{2}{*}{ 10. 1.-10.2.2014 } & \multirow{2}{*}{32} & $20 \mathrm{~cm}$ & $40 \mathrm{~cm}$ & $20 \mathrm{~cm}$ & $40 \mathrm{~cm}$ & $20 \mathrm{~cm}$ & $40 \mathrm{~cm}$ \\
\cline { 2 - 8 } & & 32 & 32 & 100.00 & 100.00 & 0.90 & 0.88 \\
\hline
\end{tabular}

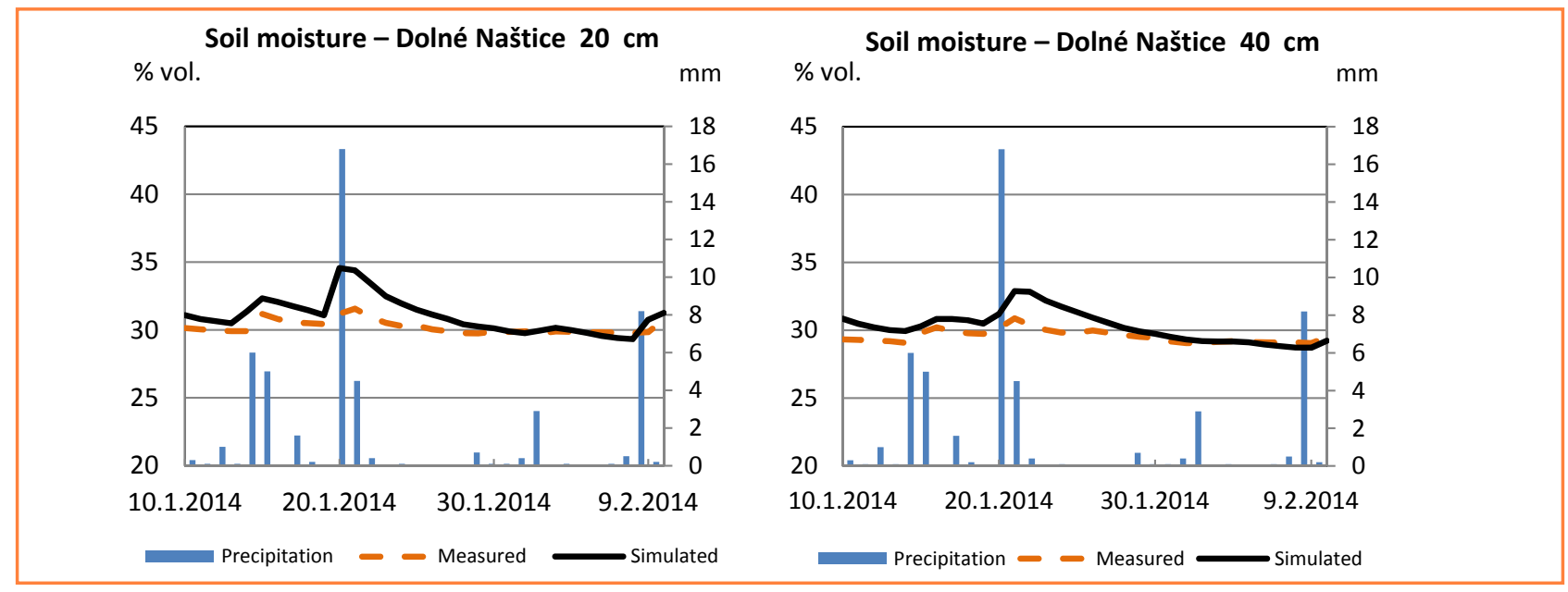

Figure 3 Measured and simulated data of soil moisture in the locality of Dolné Naštice

Figures from 1 to 3 and tables from 1 to 3 show the comparisons of measured and simulated soil moisture data.

We can declare that our simulations are valid due to values of the correlation coefficient. Many authors have similar research outputs from HYDRUS 1D model validity check. For example, according to Haishen et al. (2009) the soil water content predicted with HYDRUS was found to be in good agreement with experimental measured data.

\section{Conclusion}

As direct soil moisture monitoring is time and money consuming, indirect methods of soil moisture measurement are considered very important nowadays. The aim of this paper was to evaluate one of the most used mathematical models for soil moisture simulation - HYDRUS 1D model. Validity check of HYDRUS 1D model was performed by calculation of the correlation coefficient and count of comparisons with variance of $15 \%$. Based on our results, we can say that HYDRUS 1D model can be used for soil moisture simulation in conditions of the Slovak Republic. Outputs of the soil moisture simulation in various conditions obtained by modelling could be a good basis for landscape planning or an interesting extension for information systems about landscape (Muchová et al., 2016). As an example of practical application we can mention the information system for land consolidation OKTOPUS (Leitmanová et al., 2013) developed by our faculty.
Acknowledgment

This study was supported by projects APVV-0512-12; 08-GA SPU-16; and KEGA 019SPU-4/2017.

\section{References}

BURGER, F. - LÁTEČKA, M. 2005. Modelling and numerical simulation of irrigation water infiltration in porous media In Acta horticulturae et regiotecturae, 2005, pp. 173-177. ISSN 1335-2563.

CLAY, H. 2008. Calculating and Evaluating Validity. Scottsdale : Holcomb Hathaway, Publishers, 2008

DECAGON DEVICES. 2014. [online], [cit. 2014-03-30]. Available at: <http://www.decagon.com/products/soils/volumetric-watercontent-sensors/10hs-soil-moisture-large-area-of-influence/>

HAISHEN, L. et al. 2009. Comparison of measured and simulated water storage in dryland terraces of the Loess Plateau, China In Agricultural water management, vol. 96, 2009, p. 299-306.

JORIS, I. - FEYEN, J. 2003. Modelling Water Flow and Seasonal Soil Moistsure Dynamics in an Alluvial Groundwater-fed Wetland in Hydrology and Earth System Sciences, vol. 7, 2003, no. 1, pp. 57-66. JARABICA, V. et al. 2003. Urbanistic Plan of the Nitra city. Nitra, 2003. JURÍK, L. - KALETOVÁ, T. 2014. The evaluation of soil water storage in a small catchment in 2009 and 2010 In Acta horticulturae et regiotecturae, vol. 1, 2014, p. 1-4. ISSN 1338-5259.

KALETOVÁ, T. et al. 2012. Diagnostics of the soil water regime based on complex soil survey In Acta Hydrologica Slovaca, 2012, no. 1, pp. 28-37. ISSN 1335-6291. 
LANDSCAPE ATLAS OF THE SLOVAK REPUBLIC. 2015. [online], [cit. 2015-02-25]. Available at: <http://geo.enviroportal.sk/atlassr/>

LEITMANOVÁ, M. et al. 2013. Concept of information system for land consolidation projects In Acta horticulturae et regiotecturae, vol. 2, 2013, pp. 1-4. ISSN 1338-5259.

LEITMANOVÁ, M. et al. 2014. Accessing and archiving of spatial data from landscaping activities In Veda mladých 2014. ISBN 978-80-552-1189-3.

MUCHOVÁ, Z. et al. 2016. Possibilities of optimal land use as a consequence of lessons learnedfrom land consolidation projects (Slovakia) In Ecological Engineering, 2016, no. 90, pp. 294-306. ISSN 0925-8574.

SAIFADEEN, A. - GLADNYEVA, R. 2012. Modeling of solute transport in the unsaturated zone using HYDRUS-1D. ISSN 1101-9824.

ŠIMANSKÝ, V. - TOBISŠOVÁ, E. - CHLPÍK, J. 2008. Soil tillage and fertilization of Orthic Luvisol and their influence on chemical properties, soil structure stability and carbon distribution in waterstable macro-aggregates In Soil \& Tillage Research, vol. 100, 2008, pp. 125-132. ISSN 0167-1987. doi: 10.1016/j.still.2008.05.008.
ŠIMŮNEK, J. et al. 2012a. HYDRUS: Model Use, Calibration and Validation in Transactions of the ASABE. vol. 55, 2012, pp. 12611274. ISSN 2151-0032.

ŠIMŮNEK, J. - VAN GENUCHTEN, M. Th. - ŠEJNA, M. 2012b. HYDRUS: Model use, calibration and validation, In Special issue on Standard/ Engineering Procedures for Model Calibration and Validation, Stransactions of the ASABE, vol. 55, 2012, no. 4, pp. 1261-1274. Available at: <http://www.pc-progress.com/Documents/Jirka/ Simunek_et_al_ASABE_2012.pdf>

ŠIMŮNEK, J. et al. 2012c. The HYDRUS-1D Software Package for Simulating the One-Dimensional Movement of Water, Heat and Multiple Solutes in Variably-Saturated Media. Riverside : University of California Riverside, 2012

ZENG, Y. - SU, Z. - WAN, L. et al. 2009. Diurnal Pattern of the Drying Front in Desert and its Application for Determining the Effective Infiltration in Hydrology and Earth System Sciences, 2009, 13, pp. 703-714. ISSN 1027-5606.

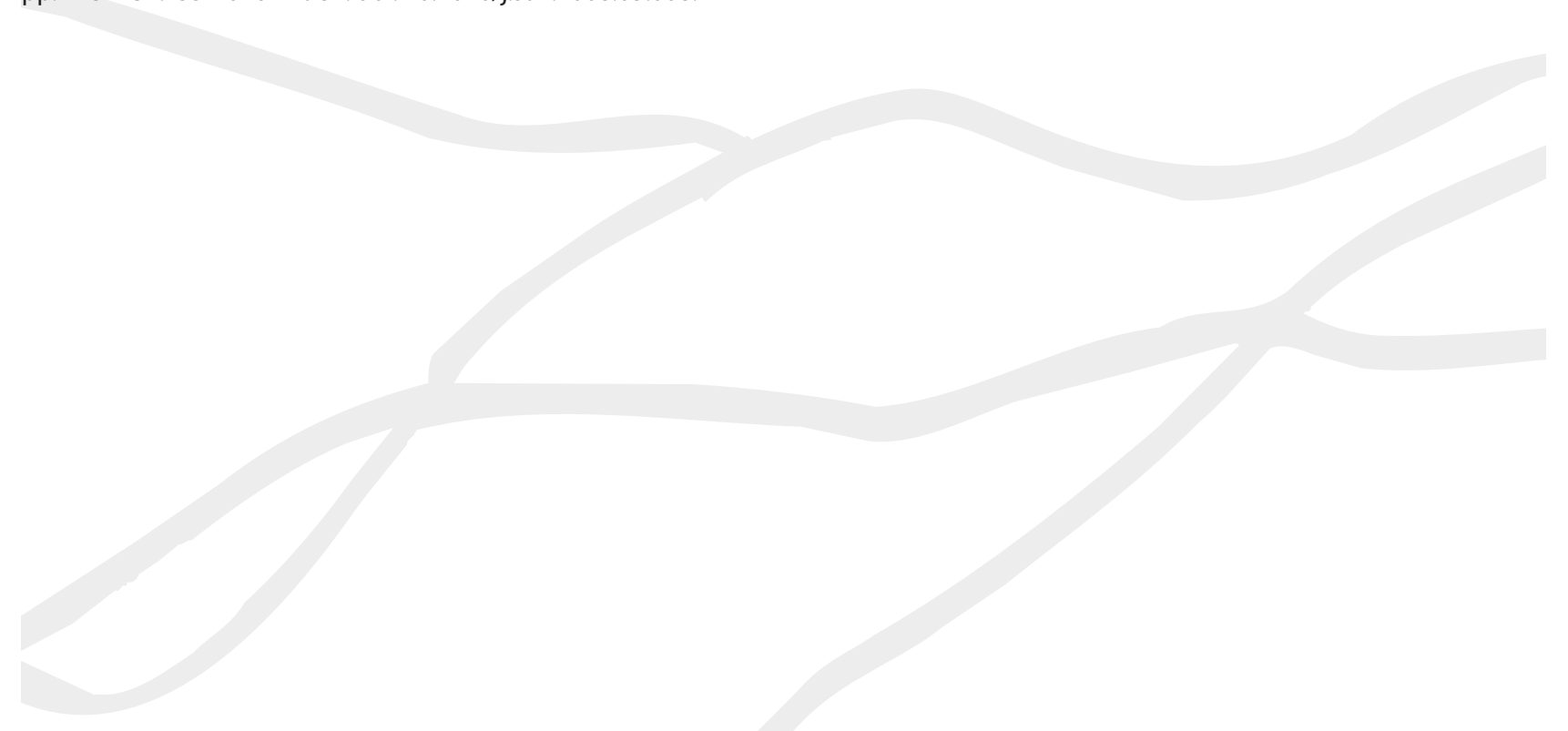

